\title{
Between entrepreneurial discourse and political awareness: an exploratory study of the Junior Enterprise Movement at a public university in Southeast Brazil
}

\author{
Marcia Prezotti PalassI ${ }^{1}$ \\ RAIANE GonçALVES DE OLIVEIRA MARTINELLI ${ }^{1}$ \\ Ana Paula paes de Paula ${ }^{2}$
}

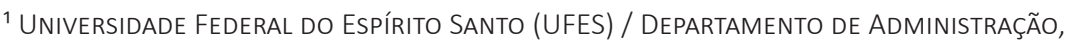 \\ Programa de Pós-Graduação em Administração, Vitória - ES, BrazIL \\ 2 Universidade Federal de Minas Gerais (UFMG) / Departamento de CIÊNCIAS AdMINISTRATIVAS, \\ Centro de Pós-Graduação e Pesquisas em, Belo Horizonte - MG, Brazil
}

\begin{abstract}
This article aims to understand the dynamics of political awareness in the Movimento Empresa Júnior (MEJ), examining its role in fostering citizen education and collective identification of junior entrepreneurs, on one of the campuses of a federal public university in southeastern Brazil. The discussion is based on the Political Consciousness Analysis Model for understanding the participation in collective actions by Sandoval (2001). It is a qualitative research, whose data were collected through participant observation, questionnaires, focus groups and semi-structured interviews, submitted to content analysis. It is concluded that the MEJ presents the structure of a "movement", because it is closer to the ideas of a business organization, which values entrepreneurial discourse. In addition, the absence of a more solid collective identity weakens the notion of political awareness among junior entrepreneurs. Thus, the MEJ's role as a promoter of political awareness and the participation of managers, which would bring complementarity between professional and citizen training, appears limited.
\end{abstract}

Keywords: Political awareness. Participation. Collective actions. Junior Enterprise Movement.

\section{Entre o discurso empreendedor e a consciência política: estudo exploratório do Movimento Empresa Júnior em uma universidade pública no Sudeste do Brasil}

\section{Resumo}

Este artigo visa compreender a dinâmica da consciência política no Movimento Empresa Júnior (MEJ), examinando seu papel no fomento da formação cidadã e da identificação coletiva dos empresários júniores, num dos campi de uma universidade pública federal no sudeste do Brasil. A discussão se baseia no Modelo de Análise da Consciência Política para compreensão da participação em ações coletivas de Sandoval (2001). Trata-se de uma pesquisa qualitativa, cujos dados foram coletados através da observação participante, questionários, grupos focais e entrevistas semiestruturadas, submetidos à análise de conteúdo. Conclui-se que o MEJ apresenta a estrutura de um "movimento", pois se aproxima mais do ideário de uma organização empresarial, que valoriza o discurso empreendedor. Além disso, a ausência de uma identidade coletiva mais sólida, enfraquece a noção de consciência política dos empresários júniores. Assim, o papel do MEJ como fomentador da consciência política e da participação dos gestores, que traria complementariedade entre a formação profissional e a cidadã, se afigura limitado.

Palavras-chave: Consciência política. Participação. Ações coletivas. Movimento Empresa Júnior.

\section{Entre el discurso emprendedor y la conciencia política: Estudio exploratorio del Movimiento Empresa Júnior en una universidad pública en el sudeste de Brasil}

\section{Resumen}

El objetivo de este artículo es comprender la dinámica de la conciencia política en el Movimiento Empresa Júnior (MEJ) examinando su papel en el fomento de la formación ciudadana y de la identificación colectiva de los empresarios júniores en uno de los campus de una universidad pública federal en el sudeste de Brasil. La discusión se basa en el Modelo de Análisis de la Conciencia Política para comprensión de la participación en acciones colectivas de Sandoval (2001). Se trata de un estudio cualitativo cuyos datos fueron recolectados a través de observación participante, cuestionarios, grupos focales y entrevistas semiestructuradas sometidos al análisis de contenido. Se concluye que el MEJ presenta la estructura de un "movimiento", pues se aproxima más al ideario de una organización empresarial, que valora el discurso emprendedor. Además, la ausencia de una identidad colectiva más sólida debilita la noción de conciencia política de los empresarios júniores. Así, el papel del MEJ como fomentador de la conciencia política y de la participación de los gestores, que traería complementariedad entre la formación profesional y la ciudadana, parece limitada.

Palabras clave: Conciencia política. Participación. Acciones colectivas. Movimiento Empresa Júnior. 


\section{INTRODUCTION}

This article aims to understand the dynamics of political awareness within the Junior Enterprise Movement (JEM) by examining its role in fostering citizen training and junior entrepreneurs' collective identification at a campus of a federal public university in Southeast Brazil, in the 2015 management. The JEM, as a representative movement among the student movements which act in Higher Education institutions, is a crucial instrument for the debate on the demands of the participating undergraduates.

The interest in understanding these dynamics arose from gaps in research on university students' political awareness and citizen participation (PALASSI and MARTINS, 2014), and criticisms of junior enterprise (JEs), which, in general, focus on entrepreneurship to the detriment of citizen awareness, what is also a reflection of the process of commodification of educational institutions in Brazil (SEKI and SIMÃO, 2014). There is a complete subject's accountability for his/her success in this entrepreneurship valuation discourse, which ignores aspects such as public social security policies, economic situations, social conditions, political conjuncture and social life complexities, based on a notion of exacerbated meritocracy (SEKI and SIMON, 2014).

In contrast, as expression of political awareness, collective action may be a tool for socialization, participation, besides being an instrument of action to cope with social difficulties (COSTA, DELIBERADOR and SILVA, 2014). Political participation of students in Higher Education institutions is one of the main instruments of integration between teaching and extension due to the development of citizenship and inclusion in public life (AZEVEDO, 2012).

Participation is understood as the process in which two or more parties influence decision making (PATEMAN, 1992). It refers to an instrument of power that means "to be part of, take part in, or have participation in" (BORDENAVE, 2013, p. 22). According to Sandoval (2001), political awareness is what allows the individual "to be part of" individual or collective decisions, in different contexts. This awareness involves aspects of identity and beliefs related to psycho-sociological dimensions, marked by historical aspects, social interactions and the actors' experience (ANSARA, 2008).

This article adopts the Model of Political Awareness Analysis for Understanding Participation in Collective Actions, by Sandoval (2001), as a theoretical framework for its empirical approach. It is a qualitative research (CRESWELL, 2007), method that allows deepening of theoretical knowledge, performed to explain participants' behaviors and attitudes, considering subjectivities in their respective historical and social contexts.

This article aims to fill a gap in studies on the subject. It is worth mentioning that, when conducting a (inter) national literature review on the movement, there was no identification of works that discuss political awareness and JEM members' participation either in collective actions of the movement or in other actions of this nature related to the JEM objectives.

Besides this introduction, this article is divided into four parts, namely: second part describes the theoretical framework, in order to ground the study; third part describes the research methodology; fourth part presents the results; and fifth part exposes the final considerations.

\section{MODEL OF POLITICAL AWARENESS ANALYSIS}

Participation facilitates growth of the subjects' critical awareness, strengthens their claiming power, and prepares them to acquire greater power in society (BORDENAVE, 2013). It is a human being's vital necessity, and refers to a collective experience that can only be learned through interactions. Participation is a process that implies equal political power in decisions, through two or more parties that influence the decision-making process, contributing to the improvement of its efficiency (PATEMAN, 1992).

Demo (1993) emphasizes that it is important to understand participation as a process of conquest and self-promotion; as a way of power that presupposes commitment, involvement, presence in risky actions and democratic exercise. It is an instrument of political participation. According to Bordenave (2013), the motives that lead to participation express the subjects' real interests to perform an action. Participation comes from the pleasure of doing something with others, and/or because doing so is more advantageous. 
In this context, collective action involves opportunities for collective mobilization, that is, what motivates subjects to act in collective situations in order to achieve the desired objectives (SANDOVAL, 2001). Such opportunities do not arise equally; they have multiple ways and reach different levels of society (PALASSI and MARTINS, 2014). According to Gamson (1992), collective action refers to an extension of meanings and orientations developed through social relations. In daily life, the individuals engage in social relations and form their awareness of society (SANDOVAL, 1989). Political awareness is understood here as a psychosocial concept referring to the meanings that individuals attribute to their interactions and experiences (SILVA, 2001). It refers to the meanings constructed by the subjects in their interactions with society, and it is, therefore, contingent (SOUZA, PALASSI and SILVA, 2015). Political awareness is what allows individuals to analyze the best action to be employed in political contexts and in specific situations faced by them (LUGON and PALASSI, 2012).

When studying political awareness, it is fundamental to consider the context of insertion of the subjects, since political awareness is related to the meanings that individuals attribute to everyday interactions and events in their lives (RECK, 2005; MELUCCI, 2001). It is composed of the meanings and information that interact in psycho-sociological dimensions, allowing the individuals to make the decisions considered more appropriate in different contexts (SANDOVAL, 2001).

For Sandoval (1989), political awareness involves the relationship between structural factors, interactive social relations, worldviews and conscious reflections of participation costs and benefits. In order to analyze political awareness, Sandoval (2001) proposes the Model of Political Awareness Analysis for Understanding Participation in Collective Actions. This model is composed of seven distinct psycho-sociological dimensions that constitute a set of reflections that direct individuals' actions as political actors in their society. The dimensions are: a) collective identity; b) societal beliefs, values and expectations; c) antagonistic interests and opponents; d) political efficacy; e) feelings of justice and injustice; f) movement goals and actions; and g) willingness to act collectively. These dimensions are articulated in a dynamic and non-linear way, without hierarchy levels, revealing relations between them. The collective identity refers to the feelings of belonging or identification that the individual relates to social issues. It is the starting point for participation in collective actions (MELUCCI, 1995). For Sandoval (2001), it is the way individuals establish an identification of interests and feelings of solidarity and belonging with a collective actor. It relates to social, political, economic, educational, and cultural investments that are valued. Costa (2012) points out that this concept is related to the psychological identification of a feeling of solidarity, enabling the individuals to develop social bonds that lead to a feeling of social cohesion.

Societal beliefs, values, and expectations refer to how individuals perceive reality. They are social representations produced in individuals' experience and interaction with diverse groups, institutions and contexts (TAJFEL, 1981). This dimension supports the construction of subjects' identities. They are the subjects' worldviews, that is, the meanings they give to social structure and institutions, and their insertion into them. Subject individualization occurs from the process of internalization of beliefs and societal values (SILVA, 2007). Souza, Palassi and Silva (2015) add that this dimension reveals how the individuals interpret reality which they are inserted into, and are made up of subjects' political ideology and worldview. They relate to interactions and experiences lived by the individuals, are not fixed and have a changeable character. They are contingent and constructed in the socio-historical context of each individual (SANDOVAL, 2001). Relationships are usually maintained individually; however, they are constructed through the interactions that each person attributes to the different senses, according to his/ her perception (AZEVEDO, 2012). Sandoval (1994), according to Heller (1972), considers spontaneity the main characteristic of daily life, causing the individual to assimilate facts, beliefs, behaviors, etc., without reflections, stimulating the development of a common sense awareness (LUCKMANN, 1967), circumscribed to routine life.

The way that material and symbolic interests oppose the interests of other groups is described by Sandoval (2001) as antagonistic and adversarial interests. Based on Tilly (1978), Sandoval understands that the totality, in this dimension, is seen in a fragmented, nebulous and superficial way, causing the individuals to identify with their class, but collaborating with groups of their daily interaction by sharing similar contextual interests. Opponents are identified based on "here and now." The identification of antagonistic interests is fundamental, because when a visible opponent is not perceived, it is impossible to mobilize individuals to act and coordinate actions against a specific target, whether an individual, an institution or a group (SILVA, 2007).

Political efficacy refers to persons' feelings about their ability to intervene in a political situation, to the feeling of the subjects perceiving their power to intervene so that to change reality (RECK, 2005). To describe this dimension, Sandoval 
(2001) relies on the attribution theory of Hewstone (1989), in which people can assign a causal link to three loci: in the first, events can be the result of transcendent forces; in the second, self-responsibility; and in the third, other's externalization and blame.

The feelings of justice and injustice are understood as feelings of social reciprocity between individuals, and the violation of this reciprocity is understood as situations of injustice (SILVA, 2009). Sandoval relies on the concept of social justice of Moore (1978), inherent in the expression of feelings of reciprocity between obligations and rewards, whose imbalance is often brought about by complex socio-historical processes. When feelings of reciprocity do not occur or are violated, that is, in situations of injustice, there is collective discontent, generating manifestations and protests. For Lugon and Palassi (2012), this dimension is related to the maintenance of the integrity of relations of reciprocities expected by the individual.

The predisposition of an individual to perform a set of collective actions is another dimension called willingness to act collectively. Sandoval (2001) relies on Klandermans (1992), who considers this dimension rather an individual's instrument than a predisposition to engage in collective actions aimed at redressing injustices, focused on situations that condition collective participation: cost-benefit ratio to interpersonal loyalty; cost-benefit ratio to profit and loss, and physical risks resulting from participation, and assessment of individual's ability to organize the movement to implement the proposed collective actions. In this dimension, predisposition to participating in collective actions can be assessed through the actors' proposals and their respective engagements (PALASSI, 2011), involving the perception between costs, benefits, and learning ratios, compensating physical-financial degradation (SOUZA, PALASSI and SILVA, 2015).

The goals and actions of the movement refer to the participants' perception of reciprocity between the objectives of the process, who participate with their strategies, feelings of injustice, political efficacy, and material and symbolic interests (SANDOVAL, 2001). In this dimension, individuals evaluate the relations between the goals of the movement and its leadership as methods compatible or not with their material or symbolic interests (PALASSI, 2011). This dimension allows us to gather the other components and perceive the organization of the movement by conducting a psycho-sociological direction for collective action (SANDOVAL, 2001).

The dimensions of the model of Sandoval (2001) characterize the set of representations and meanings that direct the participation of subjects in their society as political actors (SOUZA, PALASSI and SILVA, 2015). Based on these dimensions, it is possible to understand the factors that lead people to (not) participate in collective actions. The methodological approach of this study is presented below.

\section{METHODOLOGOCAL ASPECTS}

It is an exploratory-descriptive study (SÁ-SILVA, ALMEIDA and GUIDANI, 2009), and its empirical approach is based on qualitative methods (CRESWELL, 2007). It focuses on observation, classification and description of the dimensions of the dynamics of political awareness within the JEM and the participation of JEs managers in this movement at a campus of a federal public university in Southeast Brazil.

In the data collection, documentary research (SÁ-SILVA, ALMEIDA and GUIDANI, 2009), semi-structured interviews (BAUER and GASKELL, 2002) and focus groups (GUI, 2003) were used. Using these techniques jointly aims to complement information so that to fill potential gaps. The documents were obtained through the official websites of the Brazilian Confederation of Junior Enterprises, State Federation and respective participating JEs, social media research and articles that contained the term "junior enterprise" in their keywords. For the (recorded and transcribed) interviews and the focus groups, a script was adopted based on the dimensions of political awareness of Sandoval (2001). The data were submitted to content analysis (BARDIN, 2011), in which the dimensions of the model of Sandoval (2001) constituted pre-defined analytical categories.

The definition of subjects was based on the following criteria: CEOs of junior companies in the second half of 2015 at the federal university studied; chairmans of the Brazilian Confederation of Junior Enterprises and State Federation; commitment to participating in the research by providing information and documents, answering questionnaires, granting interviews and accepting to participate in five meetings previously scheduled with the researchers, which were the focus groups, besides signing the Informed Consent Form. The chairman of the Confederation did not accept to participate in the research. Research 
participants attended administration, social communication, economics and civil engineering undergraduate courses at the university where the JEs were estalished, and all were CEOs of the junior enterprises and Federation; five were female and only one male; ages ranged from 20 to 21 years, and the mean length of stay in the JEM was 24 months.

\section{JUNIOR ENTERPRISE MOVEMENT}

In 1967, at the École Supérieure des Sciences Economiques et Commerciales (ESSEC) in Paris, France, the first junior consulting company was created, called Junior ESSEC by Pierre-Marie Thauvin. It was an initiative of undergraduate students, who realized it was necessary to complement their studies. Thus, they created an association that provided an entrepreneurial reality to develop theory and practice (ESSEC, 2019).

In 1969, due to the initiative of Junior ESSEC, the Junior Enterprise Movement was created, giving rise to the first National Confederation of Junior Enterprises (ESSEC, 2019). The European Confederation of Junior Enterprises (JADE) was founded in 1992 by the French Federation in cooperation with the confederations of the Netherlands, Portugal, Italy and Sweden (JADE, 2015). This institution was aimed at strengthening and disseminating the Junior Enterprise Movement (JEM) around the world, seeking greater representativeness of junior companies (CARRIERI and PIMENTEL, 2005).

The movement expanded to other countries, arriving in Brazil in 1988, through João Carlos Chagas, director of the FranceBrazil Chamber of Commerce (CCFB). Formally, in 1989, the first junior company in Latin America, called Empresa Júnior Getulio Vargas (Getulio Vargas Junior Company) (EJFGV, 2015), was created in São Paulo, aiming at "supporting entrepreneurs and managers of companies by directing strategic decision making, generating impact on organization's current and future results." According to Carrieri and Pimentel (2005), EJFGV elaborated a manual of JE creation that encouraged the emergence of several junior companies in Brazil.

Among the main positive results pointed out in the recent researches that involve JEs, there are contributions related to training of junior entrepreneurs, such as the inclusion of university students into the labor market, and opportunity of practical application of the knowledge acquired in the classroom, (DIAS and LOPES, 2003; LIMA and CANTAROTTI, 2011). However, development of activities in the JEs is not always accompanied by disciplines that support these practices (LIMA and CANTAROTTI, 2011). In addition, Bicalho and Paula (2012) present criticisms of the JEM by discussing the symbolic violence naturalized and valued in the academic-professional environment of these companies, stimulating behavioral patterns of the status quo ideology. Costa, Deliberador and Silva (2014) consider that in the JEM there is appreciation of an idealized entrepreneurial discourse, reinforcing submission to capital demands.

For all the participants of the research that generated this article, the motivation for participation in the JEM arose from the interest in acquiring more knowledge during university undergraduate courses. Those who remained in the JEM did so because of the feeling of collective identity with the movement. However, the data analysis, presented below, indicates different conceptions of political awareness regarding permanence or not in the JEM. Only one participant out of the five of the research showed being apart from the JEM non-participatory decision making, since decisions are usually only informed and not discussed with other movement participants. For this person, who is in the area of social communication, there is lack of identification with the beliefs, values, societal expectations, goals and actions of the movement, revealing feelings of injustice in the JEM decision making. It is observed that the movement structure is closer to a business organization than to a movement. The reflection game promoted by the political awareness dimensions of the research participants leads them to make decisions about participating in JEM individual or collective actions.

\section{JEs participating in the JEM}

There are a number of initiatives to open junior companies; however, involvement in the JEM is limited. The participants understand the reason for the lack of participation in the movement in different ways. In addition, Federation's current actions are perceived as attempts to increase affiliations to the movement. Intending to strengthen the JEM, the Federation visits JEs that do not yet formally belong to the movement to clarify doubts about membership, seeking to involve and attract them, and junior companies in the studied university participating in the movement belong to different areas of formation. 
According to Pinheiro and Paula (2016), in relation to the junior companies investigated, there is valuation of a heterogeneity model that refers to the organization with a non-egalitarian distribution of power, separating it into different categories. In the case of the JEs, for example, the decision making is articulated by positions. The model observed in the JEs approaches the traditional management of "valuation of hierarchy, division of labor and discourse of meritocracy when addressing decision making and remuneration" (PINHEIRO and PAULA, 2016, p. 244).

Meritocracy value was widely discussed by the members at different moments, since they emphasized that, despite portraying a political ideology assimilated in the JEM, they perceived that this "meritocracy" is not adapted to the Brazilian society, and there are decisions that are not compatible with a meritocratic posture within the movement itself. The meritocratic ideology proposes that the rewards should be due to merit, and manifests itself through the entrepreneurship discourse. Its advocates argue that it allows greater justice for not considering distinctions by sex, ethnicity, and social class, among other biological or cultural factors (BARBOSA, 2014; RAMOS, 2014). For Filion (2000), entrepreneurs' actions have a lot to do with how they interpret what is happening in a particular sector of the environment.

However, it is emphasized that this positioning privileges those who were subjected to the best conditions of life in view of their respective socio-historical constitutions (DE ANDRÉ, 2013; ANDERSON, 2015). The incentive based on individualism, focused on characteristics and abilities, favors social and economic inequalities, and masks privileges (WARIKOO and FUHR, 2014; CLYCQ, NOUWEN and VANDENBROUCKE, 2014). It is noted that the idea of success does not depend exclusively on individual effort, but also on several other factors.

Therefore, the contributing factors for member participation in the JEs are related to junior entrepreneurs' collective identity. Feeling of belonging and development of common interests are the factors that stimulate participation in the movement, according to Sandoval (2001). The intention to improve their studies is one of the great motivators for the participation in the JEs. However, it is perceived that the expectation about this training sometimes distances the juniors from the academic teaching proposal, since they seek preparation strongly directed toward qualification in the job market.

In addition, by engaging in these activities, they minimize the importance of formal education by questioning the applicability of the courses offered, and confusing them with technical and business education, since a single acting format centrality can be observed in their speeches, directed at acquisition of monetary results (COSTA and SARAIVA, 2012). For Fattori, Pozzi, Marzana et al. (2015), what moves people to participate in the movement is the collective identity, the perception of injustice and collective action to restore social equality, and the idea of political effectiveness, which is a positive expectation and the basis of a group, with the possibility of being effective in changing an unfair status quo.

In the discourse of all participants of the research and in the data presented in the JEs and JME documents, the change which they refer to relates to the expectations of a better country in terms of results provided by entrepreneurship actions. In other words, they see this kind of transformation in students as a way to impact the whole country. Costa and Saraiva (2012) describe that there are few studies on entrepreneurship in junior companies. However, they emphasize that the performance of young entrepreneurs is always positive for professional development. Nevertheless, as these authors point out, entrepreneurship has become an "ideology of the new capitalist spirit that needs to be questioned" (COSTA and SARAIVA, 2012, p. 611, our translation).

The ideals of transformation, however, are not very clear. In the speeches, despite the recurring discourse of change and country transformation, it is possible to note that the concrete transformations expressed through participation and political actions in the JEM are not observed. They are mechanical discourses, based on the entrepreneurial ideals, and little contextualized in their experiences, due to the ambiguity between what they describe and their own actions.

\section{Mechanisms of participation in the JEM}

The mechanisms of participation in the JEM identified during the research were linked to events carried out by the movement itself. However, the participants of this research highlight the selective character of the events due to the high cost for participation, thus causing feelings of injustice in all participants. In general, there is a sense of belonging within the EJs, reinforced by feeling of collective identity, but when it is about the JEM, it is evident that there is not adhesion of all participants. The difficulty of adhesion is interpreted in multiple ways by the respondents: JEM detachment from the JEs; elitist characteristics of movement actions; and JE dynamics itself. 
Moreover, JE's demands require a lot of involvement in routine activities, besides the high turnover rate in these companies. When people stay a longer period in the JE, they develop and understand the JEM purpose, becoming part of the movement. However, within the movement itself, there are perceptions that disagree with the JEM actions, that is, groups with antagonistic adversary interests in relation to the movement, such as those that stand against the values of meritocracy and elitism that permeate the JEM. Thus, the organization of the movement acts as something that selects and privileges, benefiting more favored portions of junior populations (PARKINS and SINCLAIR, 2014; MORRISON and DUNLAP, 1986). Therefore, economic contradictions, inequalities, relations of power and domination existing in society are reinforced in the movement.

Participation practices are constructed in different ways, and each construction can only be understood in the context in which it is situated (DEAN, 2014). In addition to the events, the participants consider the gatherings, councils, actions and local events promoted by the Confederation, as well as the various instances of the movement, as mechanisms to promote participation. Although the participants recognize the various channels of participation in the movement, it is worth questioning the quality of this participation. Among the interviewees, there was only one person who presented concerns about these issues. Such a position, more critical and questioning, seems to have a strong relation with the academic background that this student had in the undergraduate course. The others, who are taking courses of a more positivist and functionalist nature, cannot perceive the ways of power control in the JEM. This same participant, who was in conflict with the others, added that the JEM's awards and evaluation standards are always focused on a single type of ideal organization, disregarding other possibilities for action, thus reinforcing the statements of Bicalho and Paula (2012), who mention the centrality of action possibilities.

In addition, they highlight a dominant discourse as a single possible model for generating wealth in contemporary capitalist society, valuing the centrality of the company and the development of an indispensable entrepreneurial culture (COSTA and SARAIVA, 2012). Moreover, this same representative of the movement in the state points out that most of the other members that belong to the EJ have interest only in the technical learning, that is, they do not participate and do not show interest in more critical questions that develop personal abilities.

In this context, it is necessary to encourage students to produce knowledge - not just reproduce it (ABDEL-HALIM, 2011). Most students, according to the author, do not approach a critical reading that would lead them to a more critical thinking and a broader political awareness, focusing on discourse superficiality.

\section{Junior enterprise member participation in JEM collective actions}

The leaders interviewed evaluate that they have great participation in JEM collective actions. For all interviewees, participation in these actions is encouraged by all management representatives and the other members. However, commonly it is observed that the statements present only the leaders' positioning, that is, they almost always happen in the singular and do not relate to or integrate with the other subjects in the contexts of participation in the movement collective actions.

However, they acknowledge that this great participation is not intensified by all members, mentioning only individual responsibility for participation in the movement actions, not considering collective responsibilities as JEM representatives. Despite criticizing the ideology of merit in their speeches, what happens in the practice is a hegemonic discourse on the valuation of individualism and entrepreneurial attitude, reinforcing what Ekman and Amna (2012) describe about the decline of a more active attitude in political participation.

Respondents also report the differentiation between participation occurring at movement level and in each JE. At the group discussions, it can be seen that all participants demonstrate that there is greater identification at the EJ level. This proximity to the JEM is not recurrent. However, these managers claim that sometimes it is difficult to conciliate participation with other student's demands. Although the interviewees' speeches reinforce the incentive to train everyone who participate in the movement, this is not the case in practice. It is observed in the actions of these leaders that some decisions are mechanical, without involvement or encouragement to participation of other members.

As much as movement favors a sense of promoting collective development, leaders' attitudes and decisions are strongly influenced by societal beliefs, values, and expectations (SANDOVAL, 2001). However, they are usually assimilated without reflection and, as pointed out by Souza, Palassi and Silva (2015), end up being mechanism of social control and obstacle to subject's politicization and awareness. However, leaders acknowledge the failure to encourage participation of other members, but they say that do not know how to encourage and promote such behavior. 
The participation of the subjects in collective actions was presented by the interviewees as a situation of great injustice, because they perceive the violation of the social reciprocity of the actions of the subjects that are involved only with more technical activities. These feelings of injustice are discussed because of the selection of events and the relation with the willingness to act collectively, as attempts to repair these injustices can be seen in the speeches of one of the interviewees, but the only way to achieve such reparation is by collective mobilization.

It is also verified that there is a reciprocity distancing between the goals and actions of the movement and his strategies of action and feelings of injustice (SANDOVAL, 2001). Some leaders in some JEs encourage participation of other members, although, as a matter of priority, executive members are the effective participation in the EJM collective actions. Participation should be understood in a contextual and situational way, hence the need to recognize the plurality of participatory logics (DEAN, 2014).

\section{JE member participation in society}

It was verified that, among the participants of the research, participation in society was already occurring before the insertion in the JEM, due to the encouragement of the family or the interest of the members who identified with this type of action. It is noted that the motives that led to participation in collective actions relate to the beliefs and expectations of these members, besides feelings of political effectiveness.

All the participants of the research affirm that the participation in collective actions in society began from religious formation. Therefore, the willingness to act collectively of these members occurred in this space, contributing to social, historical and religious formation of these subjects. When asked if this participation relates to the JEM objectives, the participants affirm that the motivation is similar, but they find it difficult to be explained. They emphasize that the interest in participating in collective actions relates to the feelings of collective identity, in the sense of belonging and solidarity developed by interpersonal ties (SANDOVAL, 2001).

Respondents, discussing the relation of participation in the JEM with other possibilities of participation in civil society, show intention to change their reality, revealing feelings of political efficacy in the face of the discourses of injustice perceived by them. Therefore, they believe in the benefits of their actions in trying to repair the injustices. In general, there is similarity between the purposes that made the participants of the research to stay in the JEM and the other society collective actions.

However, transformation and change in society are discussed in a generic way among the participants of the research, and there are few JEM actions that constitute factors impacting on these processes. This is because such transformations are attributed to the formation of the people who participate in the EJs, and who are given back to society by the EJM. However, when considering this portion, two problems are identified: the restricted number of people participating in the movement, and a single ideal format of traditional organization. Some studies indicate that citizens with greater access to education are more likely to be involved in political actions. Thus, they reveal the existence of a relation between the degree of social participation and their political awareness (EBRAHIMI, 2016; CAMPANTE and CHOR, 2012; HOOGHE and MARIEN, 2013; PERSSON, 2015). In this sense, it is highlighted that the Higher Education improves people's civic capacity and political awareness.

\section{JEM participation contributions to vocational training}

Participants of the research revealed that participation in EJ allowed them to improve technical questions transmitted in the classroom; courses that emerge for technical development, and the practical context provided by this experience. However, the greatest contribution refers to the development of individual personal competences, such as leadership, planning, team management, communication and oratory, entrepreneurship and focus on results.

Based on these reports, it is observed that the main objective of the movement focuses on the qualification and training of junior members, that is, on the learning acquired from the activities developed in the JEs management. However, some participants affirm that intense dedication sometimes undermines their performance in the classroom, because the excess of energy investment in their participation in the JEM forces them to prioritize some activities, and it is not possible to reconcile different responsibilities at the same time. 
It was possible to identify some difficulties in learning, such as the discontinuity between the actions of one direction and another during the process of management change. This fact is directly related to the quite intense staff turnover, and which it is necessary to meet the one-to-wo-year period of stay in the JE. According to Hellwig and Carrion (2007), the high turnover rate is considered as one of the main barriers of the participatory process, inhibiting the establishment of a significant connection, hampering the development of political and social participation of junior entrepreneurs, and harming citizens' training.

In this context, the researchers proposed to junior entrepreneurs an action-training program in participatory methodologies to generate greater participation in the decision-making process, learning of collective work methods, and greater engagement of the JEM managers. This program was approved by the management of one of the JEs in 2014, but was refused by the JES management in 2015, arguing that their weekly dedication to routine activities at these companies did not allow them to assume more responsibilities, although they recognized that the program could ease the criticism of the movement and the problems identified in this study.

In view of the above, it can be said that JE members' beliefs, values and societal expectations are ideologically in accordance with goals and actions of the movement, since they are based on the predominance of hegemonic discourses on entrepreneurship, valorization of a type of organization (private company) and management model (heterogeneity), as well as on the development of entrepreneurial skills aimed at insertion into the labor market in the private sector, making it difficult to insert new work proposals that do not align with the business movement, and revealing contradictions in the criticisms they make of the JEM.

According to Costa and Saraiva (2012), the JEs are seen as ideal environments for the development of entrepreneurial skills by connecting academic practices and market practices, suggesting that Higher Education has been rather a mechanism of reproduction of capital than an instrument of human emancipation. This context hinders the process of forming political awareness in the JEM, since, according to Althubetat and Jarrar (2013), academic practices are fundamental in the process of forming political awareness and social development.

\section{FINAL CONSIDERATIONS}

This article sought to understand the dynamics of political awareness and the participation of JE managers in the collective actions of the JEM at a campus of a federal public university in the Southeast Brazil.

It was verified the existence of different conceptions of political awareness regarding participation of the JE members in the JEM. The goals and actions of the movement motivate a portion of the subjects, but the absence of collective identity weakens their notion of political awareness, since the motivation for participation in the JEM originates from the identification with the movement, which would situate it as an instrument of formation and complementation of academic studies.

It is concluded that, despite the designation "Junior Enterprise Movement," its goals and actions, structure and context do not characterize it as a movement, since it is closer to a business organization based on an entrepreneurial discourse. Its role, from the point of view of promoting junior entrepreneurs' political awareness and participation, which would bring complementarity between vocational training and citizenship, is limited, although this is not pointed out in the movement objectives. It is worth mentioning that the representatives of the Confederation, where JEM political participation takes place, did not agree to participate in the research.

Therefore, this article does not intend to characterize a definitive position, since the research faced limitations, such as short period of permanence of the members in the JEs during the accomplishment of the research. Furthermore, there was no willingness on the part of junior entrepreneurs to develop and implement an action-training program in participatory methodologies, which could have broadened the notion of political awareness and the role of the JEM in this aspect of training.

It is recommended that future researches should deepen the results to evaluate similarities and differences in political awareness, participation of representatives of Brazil Junior (2019) in the movement collective actions and the perception of educators in managing the movement, providing a diagnosis of failures in this educational system. 


\section{REFERENCES}

ABDEL-HALIM, S. M. Improving EFL majors' critical reading skills and political awareness: a proposed translation program. International Journal of Educational Research, v. 50, n. 5-6, p. 336-348, 2011.

ALTHUBETAT, Q.; JARRAR, A. The impact of teaching political science on political awareness of Petra University students: a Jordanian case. Research on Humanities and Social Sciences, v. 3, n. 6, p. 112-121, 2013.

ANDERSON, K. T. The discursive construction of lower-tracked students: Ideologies of meritocracy and the politics of education. Education policy analysis archives, v. 23, p. 110, 2015.

ANSARA, S. Memória política: construindo um novo referencial teórico na psicologia política. Revista Psicologia Política, v. 8, n. 15, p. 31-56, 2008.

AZEVEDO, L. R. Um estudo sobre a consciência política de jovens universitários. Educação, Cultura e Comunicação, v. 3, n. 6, p. 7-22, 2012.

BARBOSA, L. Meritocracia e sociedade brasileira. Revista de Administração de Empresas, v. 5, n. 1, p. 80-85, 2014.

BARDIN, L. Análise de conteúdo. Lisboa: Ed. 70, 2011.

BAUER, M. W.; GASKELL, G. Pesquisa qualitativa com texto, imagem e som. Petrópolis, RJ: Vozes, 2002. p. 64-89.

BERGER, P. L.; LUCKMANN, T. A Construção Social da Realidade. Tratado de Sociologia do Conhecimento. Petrópolis, Vozes, 1967.

BICALHO, R. A.; PAULA, A. P. P. Empresa júnior e a reprodução da ideologia da administração. Cadernos EBAPE.BR, v. 10, n. 4, p. 894-910, 2012.

BORDENAVE, J. E. D. O que é participação. São Paulo: Brasiliense, 2013. (Coleção Primeiros Passos).

CONFEDERAÇÃO BRASILEIRA DE EMPRESAS JUNIORES - BRASIL JÚNIOR. Sancionada a lei das empresas juniores. Available at: $<$ https://brasiljunior.org.br/conhecimento/artigos/sancionada-alei-das-empresas-juniores>. Accessed: Jan. 11, 2019.

CAMPANTE, F. R.; CHOR, D. Schooling, political participation, and the economy. Review of Economics and Statistics, v. 94, n. 4, p. 841-859, 2012.

CARRIERI, A. P.; PIMENTEL, T. D. Significações culturais: um estudo de caso da UFMG Consultoria Júnior. Revista de Administração Mackenzie, v. 6, n. 3, p. 137-166, 2005.

CLYCQ, N.; NOUWEN, W.; VANDENBROUCKE, A. Meritocracy, deficit thinking and the invisibility of the system: discourses on educational success and failure. British Educational Research Journal, v. 40, n. 5, p. 796-819, 2014.

COSTA, G. B. Consciência, participação e negociação: uma leitura psicopolítica do processo de produção do Plano de Manejo da APA Várzea do Rio Tietê. 207 f. Master Thesis (Master Degree in Science) Programa de Pós-Graduação em Mudança Social e Participação Política da Escola de Artes, Ciências e Humanidades da Universidade de São Paulo, São Paulo, 2012Universidade de São Paulo, São Paulo, 2012.

COSTA, G. B.; DELIBERADOR, L. M. Y.; SILVA, A. S. Contribuições da noção de consciência política para a pesquisa e a prática da comunicação comunitária. Revista Alterjor, v. 2, n. 10, p. 26-44, 2014.

COSTA, A. S. M.; SARAIVA, L. A. S. Hegemonic discourses on entrepreneurship as ideological mechanism for the reproduction of capital. Organization, v. 19, n. 5, p. 587-614, 2012.

CRESWELL, J. W. Projeto de pesquisa: métodos qualitativo, quantitativo e misto. Porto Alegre: Artmed, 2007.

DEAN, R. Beyond radicalism and resignation: the competing logics for public participation in policy decisions. London: London School of Economics, 2014.

DE ANDRÉ, M. E. D. A. Avaliação escolar: além da meritocracia e do fracasso. Cadernos de Pesquisa, n. 99, p. 16-20, 2013.

DEMO, P. Participação é conquista: noções de política social participativa. 2. ed. São Paulo: Brasiliense, 1993.

DIAS, R. E.; LOPES, A. C. Competências na formação de professores no Brasil: o que (não) há de novo. Educação \& Sociedade, v. 24, n. 85, p. 1155-1177, 2003.

EBRAHIMI, F. Evaluation of the relationship between womens political awareness and their social participation in the contemporary society of Iran (Ardabil Province). International Journal of Asian Social Science, v. 6, n. 4, p. 262-271, 2016.

ÉCOLE SUPÉRIEURE DES SCIENCES ECONOMIQUES ET COMMERCIALES - ESSEC. Building the future with the ESSEC Foundation. Available at: <http://fondation.essec.edu/en/about-us/>. Accessed on: Jan. 11, 2019.

EKMAN, J.; AMNA, E. Political participation and civic engagement: towards a new typology. Human Affairs, v. 22, n. 3, p. 283-300, 2012.

EMPRESA JÚNIOR FUNDAÇÃO GETULIO VARGAS-EJFGV. Movimento empresa júnior. Available at: <http://ejfgv.com/sobre/>. Accessed on: Jan. 11, 2015.

EUROPEAN CONFEDERATION OF JUNIOR ENTERPRISES - JADE. The JE Network. Discover the Junior Enterprises in Europe and in the world. Available at: <http://www.jadenet.org/the-je-network/>. Accessed on: Jan. 11, 2015.

FATTORI, F. et al. A proposal for an integrated model of prosocial behavior and collective action as the expression of global citizenship. European Journal of Social Psychology, v. 45, n. 7, p. 907-917, 2015.

FILION, L. J. Empreendedorismo e gerenciamento: processos distintos, porém complementares. Revista de Administração de Empresas, v. 40, n. 3, p. 8-17, 2000.

GAMSON, W. A. Talking politics. Cambridge: Cambridge University Press, 1992.

GUI, R. T. Grupo focal em pesquisa qualitativa aplicada: intersubjetividade e construção de sentido. Revista Psicologia Organizações e Trabalho, v. 3, n. 1, p. 135-159, 2003.

HELLER, A. O Cotidiano e a História. Rio de Janeiro: Paz e Terra, 1972.

HELLWIG, B. C.; CARRION, R. M. A participação no processo decisório: um estudo na economia solidária. Revista de Gestão, v. 14, n. 4, p. 1-14, 2007. 
HEWSTONE, M. Causal attribution: from cognitive processes to collective beliefs. San Francisco, CA: Wiley Blackwell, 1989.

HOOGHE, M.; MARIEN, S. A comparative analysis of the relation between political trust and forms of political participation in Europe. European Societies, v. 15, n. 1, p. 131-152, 2013.

KLANDERMANS, B. Mobilization and participation: social psychological expansion of the resource mobilization theory. American Sociological Rewiew, n. 49, p. 583-600, 1992.

LIMA, T. F.; CANTAROTTI, A. A formação e a construção de competências para a atuação do profissional de secretariado executivo: um estudo de caso em uma empresa júnior. Revista de Gestão e Secretariado, v. 1, n. 2, p. 94-122, 2011.

LUGON, A. P.; PALASSI, M. P. Participação dos núcleos de defesa civil do município de Vitória na gestão de desastres naturais. Revista Psicologia Política, v. 12, n. 24, p. 345-361, 2012.

MELUCCI, A. The process of collective identity. Social movements and culture. Minneapolis, MN: University of Minnesota, 1995. v. 4, p. 41-63.

MELUCCI, A. A invenção do presente: movimentos sociais nas sociedades complexas. Petrópolis, RJ: Vozes, 2001.

MOORE, B. Injustiça: a base social da obediência e revolta. São Paulo: Cortez, 1978.

MORRISON, D. E.; DUNLAP, R. E. Environmentalism and elitism: a conceptual and empirical analysis. Environmental Management, v. 10, n. 5, p. 581-589, 1986.

PALASSI, M. P. Ações coletivas e consciência política no mundo do trabalho: dilemas subjetivos da participação nos processos de privatização. Curitiba: Juruá, 2011.

PALASSI, M. P.; MARTINS, G. F. Consciência política e participação cidadã dos estudantes de administração de uma universidade pública federal no Sudeste do Brasil. In: SEMANA DE CIÊNCIAS SOCIAIS DA UNIVERSIDADE FEDERAL DO ESPÍRITO SANTO, 2014, Vitória. Anais... Vitória: Universidade Federal do Espírito Santo, 2014. Available at: <http://www.periodicos.ufes.br/SCSUFES/article/view/8573/6030>. Accessed on: Jan. 11, 2019.

PARKINS, J. R.; SINCLAIR, A. J. Patterns of elitism within participatory environmental governance. Environment and Planning C: Government and Policy, v. 32, n. 4, p. 746-761, 2014.

PATEMAN, C. Participação e teoria democrática. Rio de Janeiro: Paz e Terra, 1992.

PERSSON, M. Education and political participation. British Journal of Political Science, v. 45, n. 3, p. 689-703, 2015.
PINHEIRO, D. C.; PAULA, A. P. P. Autogestão e práticas organizacionais transformadoras: contribuições a partir de um caso empírico. Desenvolvimento em Questão, v. 14, n. 33, p. 233-266, 2016.

RAMOS, V. R. G. Meritocracia na educação e a luta dos trabalhadores contra a precarização. Em Debate, n. 11, p. 47-67, 2014.

RECK, J. A consciência política dos cooperados do MST: o caso do COOPAC-Campo Verde/MS. 245f. Tese (doutorado) - Programa Pós-Graduação em Educação, Universidade Estadual de Campinas - Faculdade de Educação. Campinas, 2005.

SANDOVAL, A. M. S. Considerações sobre aspectos micro-sociais na análise dos movimentos sociais. Psicologia e Sociedade, n. 7, p. 61-72, 1989.

SANDOVAL, A. M. S. The crisis of the Brazilian labor movement and the emergence of alternative forms of working-class contention in the 1990s. Revista Psicologia Política, v. 1, n. 1, p. 173-195, 2001.

SANDOVAL, S.A.M. 1994. Algumas reflexões sobre cidadania e formação de consciência política no Brasil. In: M.J.P. SPINK (org.), A cidadania em construção: uma reflexão transdisciplinar. São Paulo, Cortez Editora, p. 59-74.

SÁ-SILVA, J. R.; ALMEIDA, C. D.; GUINDANI, J. F. Pesquisa documental: pistas teóricas e metodológicas. Revista Brasileira de História \& Ciências Sociais, v. 1, n. 1, p. 1-15, 2009.

SEKI, A. K.; SIMÃO, C. R. P. Por que "não" a uma EJ: o que é inconciliável entre a universidade pública e as empresas júniores? Revista Psicologia Organizações e Trabalho, v. 14, n. 4, p. 475-480, 2014.

SILVA, A. S. Consciência e participação política: uma abordagem psicopolítica. Interações, v. 6, n. 12, p. 69-90, 2001.

SILVA, A. S. A identificação de adversários, de sentimentos antagônicos e de (in)eficácia política na formação da consciência política no MST Paulista. Estudos e Pesquisas em Psicologia, v. 7, n. 1, p. 105-126, 2007.

SILVA, A. S. Luta, resistência e cidadania: uma análise psicopolítica dos movimentos e paradas do orgulho LGBT. Curitiba: Juruá, 2009.

SOUZA, L. V. S.; PALASSI, M. P.; SILVA, A. R. L. Consciência política e participação no orçamento participativo em Cachoeiro de Itapemirim (ES, 2009-2012). Ciências Sociais Unisinos, v. 51, n. 2, p. 161-172, 2015.

TAJFEL, H. Categorização social, identidade social e comparação social. Grupos Humanos e Categorias Sociais. Lisboa: Horizonte, 1981. v. 2, p. 289-303.

TILLY, C. From mobilization to revolution. New York: McGraw-Hill, 1978.

WARIKOO, N. K.; FUHR, C. Legitimating status: perceptions of meritocracy and inequality among undergraduates at an elite British university. British Educational Research Journal, v. 40, n. 4, p. 699717, 2014. 
Márcia Prezotti Palassi

ORCID: https://orcid.org/0000-0002-0751-6777

Doctorate degree in Social Psychology from the Pontifical Catholic University of São Paulo (PUC-SP); Professor at the Administration Department and at the Program of Graduation in Administration (UFES), Vitória- ES, Brazil. E-mail: mprezotti@hotmail.com

Raiane Gonçalves de Oliveira Martinelli

ORCID: https://orcid.org/0000-0003-0896-0746

Master's Degree in Business Administration from the Federal University of Espírito Santo (UFES), Vitória- ES, Brazil. E-mail: raianemartinelli@gmail.com

Ana Paula Paes de Paula

ORCID: https://orcid.org/0000-0001-8035-472X

Doctorate degree in Social Sciences from University of Campinas (UNICAMP); Professor at the Administration Sciences Department of Administration

Graduation and Research Center (CEPEAD/UFMG), Belo Horizonte - MG, Brazil. Email: appp.ufmg@gmail.com 